\title{
Pharmacosnogtic Characterization of Phyllanthus amarus shumach. \& Thonn Species
}

\author{
Lourdes Padró Rodríguez, Lic Ainés Figueredo Montero and Frenkel Guisado Bourzac* \\ Departamento de Farmacia, Facultad Ciencias Naturales y Exactas, Universidad de Oriente, Venezuela
}

Submission: January 04, 2018; Published: March 22, 2018

*Corresponding author: Frenkel Guisado Bourzac, Departamento de Farmacia. Facultad Ciencias Naturales y Exactas. Universidad de Oriente,

Venezuela, Email: lpadro@uo.edu.cu

\begin{abstract}
A pharmacognostic characterization of the species Phyllanthus amarus Shumach \& Thonn was carried out. The collection of the species was carried out in the Agüero urban district of Santiago de Cuba. The sample was divided into two parts, a first one was subjected to the air drying method in its two form: sun and shadow variants and the second one was used to prepare the infusion and decoction extracts. The results were processed using the IBM SPSS Statistics version 20 statistical program. The pharmacognostic parameters for the dry drug were determined according to the procedures described in the Public Health Extension Standard (NRSP) 309. The qualitative chemical composition was determined for each extract of Phytochemical and Quantitative Screening as a function of the content of the total solids by the NRSP 312 . According to the results, the best drying variant was in the sun, with a moisture content of $7.63 \pm 0.32 \%$, the highest percent of soluble substances was achieved with the $50 \%$ hydroalcoholic solution, $2.03 \pm 0.37 \%$ of water-soluble ash and $0.73 \pm 0.45 \%$ of insoluble in hydrochloric acid were obtained. The total solids content showed better results for the infusion $0.27 \mathrm{~g} / 100 \mathrm{~mL}$ obtaining a $0.46 \mathrm{~g} / 100 \mathrm{~mL}$ for the crude drug in the aqueous extract exposed to the sun. Significant differences were found in the determinations of residual moisture, soluble substances and total solids.
\end{abstract}

\section{Introduction}

Nowadays, the use of medicinal plants is increasing, partly due to the deficit of medicines and the appearance of numerous adverse reactions in many of the drugs originated from synthetic sources; however, it is necessary to intensify scientific research, thus guaranteeing the necessary scientific data that support the rational and safe use of medicinal plants and their extracts. (Farnsworth et al, 1989; WHO, 2000). According to estimates by the World Health Organization, more than two thirds of the world population use traditional treatments based on medicinal plants to solve health problems. However, the processes of transculturation affecting indigenous and peasant communities have led to the devaluation of ancestral knowledge regarding the use of these plants [1]. Phyllanthus species belonging to the Phyllanthaceae family of Angiosperms have traditionally been used as antipyretic, laxative, antibacterial, antispasmodic and antidiabetic remedies for the treatment of intestinal and urinary infections, such as antivirals, among others [2-4] in places like Cuba (Roig, 1974), the Caribbean [5], in the south and central part of America, China, Nigeria, the Philippines and Africa [611]. Pharmacological studies carried out by Morton et al. [13] with extracts of $P$. niruri, $P$. tenellus and $P$. urinaria showed that the main compounds identified in these are flavonoids, tannins and phenols [13].
In Cuba, more than 60 species of Phyllanthus have been reported as endemic, but not yet fully studied $[14,15]$. Within the genus Phyllanthus amarus Schumach \& Thonn, who has been employed mainly for the treatment of renal lithiasis in folk medicine for several years in different countries, such as Argentina, Venezuela, Brazil, India and Cuba, it is widely used in Cuba for the properties it exhibits, with high popular acceptance in the treatment of various diseases, especially in its uses for treating Diabetes Mellitus, Arterial Hypertension, and renal and vesicular lithiasis, as reported by Duharte (2016), in the ethnobotanical study conducted in two locations in the municipality of Palma Soriano, in the province of Santiago de Cuba. One of their common names is "rompe piedras" is due to its ability for breaking renal stones [14,15].

Based on the fact that the species is widely used by our population and that it their scientific studies remains still insufficient to support its use in therapeutics, it is necessary to initiate Pharmacognostic, Pharmacological and Toxicological studies that scientifically endorse the popular and traditional use that shows the species following the Critical Path of Research in Medicinal Plants that establish the national and international norms for the study of vegetal species [16]. The objective of the 
present work is to determine pharmacognostic parameters of the species Phyllanthus amarus Schumach \& Thonn.

\section{General characteristics of the research}

A pharmacognostic study was carried out on the species Phyllanthus amarus Schumach. \& Thonn in the period comprising February-April 2017, carried out in the Pharmaceutical Technology laboratories of the Department of Pharmacy of the Faculty of Natural and Exact Sciences of the Universidad de Oriente in Santiago de Cuba. The taxonomic identification of the species was corroborated by a specialist of Vegetal Taxonomy from the Eastern Center of Ecosystem and Biodiversity (BIOECO) located at the Natural Museum History “Tomás Romay "located at the city of Santiago de Cuba.

For the pharmacosnogtic characterization, measurement were carried out using a fresh drug batch of the plant material collected between 5-20 February 2017, collected during the morning in a farm located in the Agüero neighborhood, in the province of Santiago de Cuba. The material was processed by air-drying in two processing ways: sun and shade variants; and resulting materials were submitted for determining the pharmacognostic parameters [17]: residual moisture content by two gravimetric (loss of drying) and infrared methods, total ashes, soluble in water and insoluble in hydrochloric acid and soluble substances, using as mixtures solvents.

The IBM SPSS Statistics Version 20 software was used to analyze the results obtained through ANOVA to identify significant differences between groups for a confidence level of 0.05. P. amarus can de generally described as follows: is an erect, glabrous plant with translucent latex and profusely branched, where lateral branches have the appearance of composite leaves. Flowers are unisexual and arranged in the armpit of the leaves. Feminine flowers have 5 sepals, a star disc and a smooth ovary. The leaves are simple and alternate, subsessile with the base of the petiole surrounded by two very small filiform stipules (1.5mm long), which quickly blacken. The limbus is elliptical to oblong with a rounded apex, sometimes briefly apiculated. They have a length of 8 to $12 \mathrm{~mm}$ and widths of 3 to $4 \mathrm{~mm}$. The margin is whole and both sides are glabrous. The lower face is glaucous.

The most effective air drying method were the sun variant (constant weight at 7 days). For both variants, the vegetal material took a green-brown coloration. These results can not be compared because there are no reports of drying studies for Table 3: Results of extractable or soluble substances determination.

\begin{tabular}{|c|c|c|c|c|c|c|c|c|c|c|}
\hline & \multicolumn{2}{|c|}{$\mathrm{H}_{2} \mathrm{O}$} & \multicolumn{2}{|c|}{ HS $10 \%$} & \multicolumn{2}{|c|}{ HS 30\% } & \multicolumn{2}{|c|}{ HS $50 \%$} & \multicolumn{2}{|c|}{ HS 70\% } \\
\hline & Mean & SD & Mean & SD & Mean & SD & Mean & SD & Mean & SD \\
\hline Sun & 20,59 & $\pm 4,00$ & 21,68 & $\pm 4,22$ & 22,65 & $\pm 4,46$ & 23,65 & $\pm 3,40$ & 23,54 & $\pm 3,59$ \\
\hline Shadow & 18,19 & $\pm 0,79$ & 15,76 & $\pm 4,06$ & 20,65 & $\pm 1,23$ & 23,33 & $\pm 1,73$ & 21,14 & $\pm 1,92$ \\
\hline
\end{tabular}

Legend: HS- hydroalcoholic solution; DS- standard deviation

the species. Thus the importance for the selection of a suitable drying method that guarantees enzymatic processes that could modify the possible metabolites were not activated (Cuellar and Cuellar, 2001).

The results of the residual moisture content determination are shown in Table 1. Both values of residual moisture are within the allowable limits for unofficial drugs, which oscillates between 8-14\% (Cuellar and Cuellar, 2001), indicating that any of these methods can be used to determine the moisture content, especially when it is known that no volatiles substances are presented in this species.

Table 1: Results of residual moisture determination.

\begin{tabular}{|c|c|c|c|c|}
\hline \multirow{2}{*}{ Method } & \multicolumn{2}{|c|}{ Sun Exposure Variant } & \multicolumn{2}{c|}{ Shadow Variant } \\
\cline { 2 - 5 } & Mean & SD & Mean & SD \\
\hline Stove & $7,63 \%$ & $\pm 0,32$ & $8,13 \%$ & $\pm 0,18$ \\
\hline Infrared & $9,31 \%$ & $\pm 0,22$ & $10,53 \%$ & $\pm 0,25$ \\
\hline
\end{tabular}

Legend: SD- standar deviation.

Ash values for the dry drug are an indicator of the quality of the material used and constitute a basis for judging its purity and identity, providing information regarding possible adulteration with inorganic materials or foreign bodies that it possesses (Cuellar and Cuellar, 2001). The values obtained in the ash determination are shown in Table 2.

Table 2: Results of ash determination.

\begin{tabular}{|c|c|c|c|c|}
\hline \multirow{2}{*}{ Ashes } & \multicolumn{2}{|c|}{ Sun Exposure Variant } & \multicolumn{2}{c|}{ Shadow Variant } \\
\cline { 2 - 5 } & Mean & SD & Mean & SD \\
\hline Total ash (\%) & 6,02 & $\pm 0,30$ & 6,90 & $\pm 0,21$ \\
\hline $\begin{array}{c}\text { Water-soluble ash } \\
\text { (\%) }\end{array}$ & 2,03 & $\pm 0,37$ & 1,30 & $\pm 0,42$ \\
\hline $\begin{array}{c}\text { Insoluble ash in } \\
10 \% \mathrm{HCl}(\%)\end{array}$ & 0,73 & $\pm 0,45$ & 1,25 & $\pm 0,39$ \\
\hline
\end{tabular}

\section{Legend: SD- standar deviation}

The results obtained of total ash are between 6-6.90\%, being higher in the vegetal material dried at shade. These values are above the ashes index reported in the pharmacopoeias (Cuellar and Cuellar, 2001; Lou, 1980; WHO, 1998), which report a value no greater than $5 \%$. These results may be justified by the fact that this species grows in barren lands, which are rich in minerals, which may be part of the ignition residue resulting from the total ash determination process. 
When values obtained for total ashes are high (greater than $5 \%)$, it is necessary to know if they are composed of heavy metals, which is determined by the tests of insoluble ash, and, if this residue is high, drug must be submitted to other tests before approving for its use (Cuellar and Cuellar, 2001). The percentages of water-insoluble and acid-insoluble ash (Table 3) were $2.03 \%$ $( \pm 0.37)$ and $0.73 \%( \pm 0.45)$ respectively for sun-dried vegetable material, and of $1.30 \%( \pm 0.42)$ and $1.25 \%( \pm 0.39)$, for shadedried plant material, which are within the established limit (around 2\%) (Lou, 1980; WHO, 1998). Low concentration of ash insoluble in acid could be due to the presence of sand residues coming from the land of the collection of the species [18-20].

From the statistical analysis performed, no significant statistical differences were obtained between the drying variants used nor between the water soluble and insoluble ash in $10 \%$ hydrochloric acid. The determination of extractable or soluble substances is one of the most important numerical indices to select the best solvents in the extraction process, they are expressed in \%. The following table (Table 3) shows the values obtained for the different solvents used.

The values shown in Table 3 show that the highest percentage of extractable substances is achieved with the $50 \%$ hydroalcoholic solution while the lower percentage is obtained with water as solvent. This behavior is observed in both drying variants.

Statistical analysis revealed significant differences between the $10 \%$ and $50 \%$ solvents for the shadow variant, but not for the sun variant. These results indicate that the compounds present in the species could have structural chemical characteristics that allow them to have more affinity for the solubilization in these solvents rate.

2.2. Results of total solids in the aqueous extracts (of the dry drug) and by infusion and decoction from the fresh drug

The total solids results of the aqueous extracts obtained by infusion and decoction from the fresh drug and the dry drug are compared with the aim of determining whether there are differences in quantitative chemical composition. The mean values obtained for the infusion-decoction fresh material and for the aqueous extract in the sun and in the shade were: 0.27 ; $0.25 ; 0.46$ and $0.30 \%$ respectively. If we take into account that the aqueous extracts were made from plant material in different states (drug, raw drug) we could infer that the values of total solids have a tendency to decrease in the fresh material (infusiondecoction) since the quantity taken for the determination would include the raw material to be taken in addition to the water content of the same; on the other hand we must take into account that the dry material (raw drug) is a dehydrated material whose water content is minimal, and the amount by weight necessary for the determination of this parameter would be superior in comparison with the drug. This explains the differences in the values obtained in the different extracts, which is corroborated by the statistical analysis performed [21-27].
Both extraction methods use water as a menstrual infusion by putting the drug in contact with hot or cold water for 15 minutes, and decoction by boiling the drug together with the water for 30 minutes. With these methods, in addition to the active principle, more of the accompanying or inactive substances are extracted, although the temperature factor does not always favor the quality of the extraction (Cuellar and Cuellar, 2001).

\section{Conclusion}

The determined pharmacognostic parameters were as follows:

I. The sun variant is the best air drying method, which showed $7.63 \pm 0.32 \%$ residual moisture.

II. The largest percent of soluble substances were obtained with the $50 \%$ hydroalcoholic solution.

III. For the total ashes, the highest result was obtained for the shade; the largest percentages of water-soluble and insoluble hydrochloric acid ash were determined in the sundried sample.

Quantitative chemical composition, based on the determination of total solids, showed different values in the aqueous extracts, being higher in the extract obtained by infusion $(0.27 \mathrm{~g} / 100 \mathrm{ml})$ for the drug and for the crude drug in the aqueous extract at $(0.46 \mathrm{~g} / 100 \mathrm{ml})$.

\section{References}

1. WHO (2000) World Health Organization. Repor of the Inter-Regional Workshop on Intellectual Property Rights in the Context of Traditional Medicine.

2. Petti GR, Gragg GM, Schanfelberger DE (1988) Isolation and structure of the cytostatic lignan glycoside phyllantostatin. A J Nat Prod 51: 1104-1112.

3. Mensah JL (1990) Antibacterial activities of the leaves of Phyllanthus discoideus. J Ethnopharmacol 28 (1): 129-133.

4. Calixto JB, Santos AR, Cechinel Filho V, Yunes RA (1998) A review of the plants of the genus Phyllanthus: Their chemistry, pharmacology and therapeutic potential. Med Res Rev 18(4): 225-258.

5. Weniger, B y Robineau, L (1988) Elementos para una farmacopea caribeña. Investigación científica y uso popular de plantas medicinales en el Caribe, Seminario TRAMIL. 202.

6. Unander DW, Webster GL, Blumberg BS (1990) Records of usage or assay in Phyllanthus (Euphorbiaceae): I. Subgenera Isocladus, Kirganelia, Cicca, and Emblica. J Ethnopharmacol 30: 233-264.

7. Unander DW, Webster GL, Blumberg BS (1991) Uses and bioassays in Phyllanthus (Euphorbiaceae): a compilation. II. The subgenus Phyllanthus. J Ethnopharmacol 34(2-3): 97-133.

8. Unander DW, Webster GL, Blumberg BS (1992) Usage and bioassays in Phyllanthus (Euphorbiaceae): a compilation. III. The subgenera Ericoccus, Conami, Gomphidium, Botryanthus, Xylophylla and Phyllanthodendron, and a complete list of the species cited in the three- part series. J Ethnopharmacol 36: 103-112.

9. Unander DW, Webster GL, Blumberg BS (1995) Usage and bioassays in Phyllanthus (Euphorbiaceae). IV. Clustering of antiviral uses and the other effects. J Ethnopharmacol 45(1): 1-18. 
10. Thyagarajan SP, Subramanian S, Thirunalasundari T, Venkateswaran PS, Blumberg BS (1988) Effect of Phyllanthus amarus on chronic carriers of hepatitis B virus. The lancet 2(8614): 764-766.

11. Oliver Bever B ( 1983) Medicinal plants in tropical west Africa. III Anti-infection therapy with higher plants. J Ethnopharmacol 9: 1-83.

12. Morton JF (1981) Atlas of medicinal plans of middle América. C C Thomas pub spring field III USA, p. 142.

13. Santos AR, Filho VC, Niero R, Viana AM, Moreno FN, et al. (1994) Analgesic effects of callus culture extracts from selected species of Phyllanthus in mice. Journal of Pharmaceutical Pharmacology 46(9): 755-759.

14. Hermano Ly Hermano A (1953) Flora de Cuba. Imp. P. Fernández y Cía. Tomo III. 50

15. Gutiérrez YI ( 2011) Estudio Farmacognóstico de Phyllanthus orbicularis HBK, especie endémica de Cuba Instituto de Farmacia y Alimentos Departamento de Farmacia Universidad De La Habana.

16. MINSAP, Ministerio de Salud Pública (2012) Programa para el Desarrollo y la Generalización de la Medicina Tradicional y Natural. La Habana: MINSAP.

17. MINSAP, Ministerio de Salud Pública (1997) Guías Metodológicas para la investigación en Plantas Medicinales. Dirección de Ciencia y Técnica. La Habana: MINSAP, pp. 20-25.

18. Farnsworth NR, Akerele O, Bingel AS, Soejarto DD, Guo Z. Las plantas Medicinales en la terapéutica. Bol of Sanit-Panam 107: 4314-329.
19. WHO/EDM/TRM/2000.1. Geneva, Suiza, p. V.

20. Calixto JB, Adair RS, Niraldo P, Valdir CFR (1997) The plants of genus Phyllanthus as a potential sourse of new drugs. Natural products research in Brazil 49: 5-6.

21. Roig JT ( 1974) Plantas aromáticas o venenosas de Cuba. Editorial Ciencia y técnica, La Habana. Cuba, pp. 404-405.

22. Dhuarte (2016) Estudio etnobotánico del uso de la especie Phillanthus amarus Schumach \& Thonn en dos localidades del Municipio Palma Soriano, Santiago de Cuba. Universidad de Oriente. Facultad de Ciencias Naturales y Exactas. Departamento de Farmacia. Tesis en opción al título de Licenciatura en Ciencias Farmacéuticas.

23. Fuentes FR (1988) Estudios sobre la Medicina Tradicional en Cuba III. Estación Experimental de Plantas Medicinales Dr. Juan Tomás Roig Revista Cubana de Farmacia 22(3): 77-90.

24. Miranda M (2001) Farmacognosia y productos naturales. Editorial Félix Varela. La Habana 2001.capitulo VI, pp. 135-1142.

25. MINSAP, Ministerio de Salud Pública. 1997. Guías Metodológicas para el estudio de secado de las Plantas Medicinales. Dirección de Ciencia y Técnica. La Habana: MINSAP; pp. 20-25.

26. WHO/PHARM/80.502

27. WHO/PHARM/92.559

Your next submission with Juniper Publishers
will reach you the below assets
- Quality Editorial service
- Swift Peer Review
- Reprints availability
- E-prints Service
- Manuscript Podcast for convenient understanding
- Global attainment for your research
- Manuscript accessibility in different formats
( Pdf, E-pub, Full Text, Audio)
- Unceasing customer service
Track the below URL for one-step submission
https://juniperpublishers.com/online-submission.php

